\title{
Grading of softwood lumber using non-destructive techniques
}

\author{
Song-Yung Wang ${ }^{a}$, Jin-Hau Chen ${ }^{a}$, Ming-Jer Tsai ${ }^{a}$, \\ Cheng-Jung Lin ${ }^{b}, \mathrm{Te}$-Hsin Yang ${ }^{a, *}$ \\ a School of Forestry and Resource Conservation, College of Bioresource and Agriculture, \\ National Taiwan University, No. 1, Sector 4, Roosevelt Road, Taipei, 10617, Taiwan, ROC \\ $\mathrm{b}$ Division of Forest Utilization, Taiwan Forestry Research Institute, Taipei, Taiwan, ROC
}

\section{A R T I C L E I N F O}

Article history:

Received 6 August 2007

Received in revised form

17 October 2007

Accepted 23 December 2007

Keywords:

Non-destructive technique

Visual grading

Machine stress grading

Dynamic modulus of elasticity

\begin{abstract}
A B S T R A C T
The purpose of this study was to determine the grading and wood properties of the four softwood lumbers using non-destructive techniques. The results indicated that the higher the visual grading, the higher the values of the dynamic modulus of elasticity (DMOE) and modulus of elasticity (MOE) in bending of the lumber. Mechanical grading was more reliable and more efficient than visual grading. The value of the DMOE was slightly higher than that of the MOE, and there were good relationships between the DMOE and MOE of the lumber. Flexural stiffness as determined by the transverse vibration method was found to be the best single predictor of the MOE.
\end{abstract}

(c) 2008 Elsevier B.V. All rights reserved.

\section{Introduction}

Japanese cedar (Cryptomeria japonica) and Taiwania (Taiwania cryptomerioides) plantation trees are important resources for lumber production in Taiwan. In addition to these plantation trees, lumber manufacturers have a growing interest in obtaining Douglas fir (Pseudotsuga menziesii) and Southern pine (Pinus spp.) lumber from imported sources. However, manufacturers of structural lumber need to produce lumber which adheres to the Chinese National Standard (CNS) system, in order to receive CNS grade marks to have access to Taiwanese markets for processing and utilization. Visual grading and machine stress rating (MSR) are two methods already approved by the Taiwan Bureau of Standards, Metrology and Inspection, Ministry of Economic Affairs for grading lumber.
Visual inspection is a simple and convenient nondestructive evaluation method. The MSR method which couples visual sorting criteria with non-destructive measurements to establish a basic strength classification for wood products is used in North America (Galligan et al., 1977). Divos and Tanaka (1997) indicated the importance of the simultaneous grading of lumber based on the modulus of elasticity (MOE) in bending and appropriate visual grading. However, no documentation exists to guide the assignment of properties to lumber produced from domestic species (Japanese cedar and Taiwania) and foreign species (Douglas fir and Southern pine) following the MSR process (CNS 14633) in Taiwan. The wide application of machine stress grading in the lumber industry in Taiwan is expected to result in a greatly increased volume of utilizable lumber compared with the present visual grading methods.

\footnotetext{
* Corresponding author. Tel.: +886 2 33664641; fax: +886 223686335. E-mail address: d90625006@ntu.edu.tw (T.-H. Yang). 
Using non-destructive evaluation techniques to predict the material properties of wood is a matter of considerable importance for the timber industry. Non-destructive evaluation, by definition, is the science of identifying physical and mechanical properties of a piece of material without altering its final application capabilities (Ross et al., 1998), and such evaluations are achieved by non-destructive testing (NDT) techniques. Ross et al. (1995) also stated non-destructive evaluation (NDE) is an important tool for the characterization of wood and can be used industrially to improve process quality control through a greater uniformity of raw materials and their by-products.

Because the mechanical properties and the MOE of wood have a mostly positive linear correlation, wood scientists often judge the strength properties of wood by testing the MOE including both static and dynamic methods (Sobue, 1992; Iijima, 1993). In static method, a dead load is brought to bear on a wood specimen to its elastic limit; the MOE is calculated by the relationship of carrying capacity to the deflection degree. Compared to static method, dynamic method includes vibration method, ultrasonic wave transmission timing and stress wave transmission timing methods.

In recent years, increasing amounts of research have been conducted to investigate the feasibility of using these NDTs to evaluate timber and lumber quality. Ross and Pellerin (1991) examined the relationship between longitudinal stress waves and the static MOE for Douglas fir lumber. They found strong relationships for that, with a correlation coefficient $(r$ ) of 0.95 . Ross et al. (1991a) utilized transverse vibration techniques to estimate the quality of spruce-pine-fir lumber and observed a useful relationship between the DMOE and MOE $(r=0.99)$. Similar results were also found in various past reports (Ross et al., 1991b; Schad et al., 1995; Haines et al., 1996; Haines and Leban, 1997; Jang, 2000; Burdzik and Nkwera, 2002; Ross et al., 2005). In addition to those applications, the ultrasonic wave method is another kind of NDE technique to evaluate the MOE of lumber.

Therefore, in this experiment, Japanese cedar, Taiwania, Douglas fir and Southern pine lumbers were tested by visual inspection, an ultrasonic wave method, transverse vibration method, and static bending stress method. The interrelationships among visual grading, machine stress grading, and strength properties (NDT parameters) were also examined.

\section{Materials and methods}

\subsection{Preparation of the lumber}

For the experiments, all specimens were rectangular in crosssection ( $38 \mathrm{~mm} \times 89 \mathrm{~mm}$, nominal 2 in. $\times 4$ in.) and $3600-\mathrm{mm}$ long, and the moisture content was maintained at 15\%. A total of 198 samples of Japanese cedar sawn lumber, 302 samples of Taiwania sawn lumber, 163 samples of Douglas fir sawn lumber, and 123 samples of Southern pine sawn lumber were used for the experiments.

\subsection{Visual grading of lumber}

The visual grades of these lumber specimens were classified in accordance with specifications for type B platform lumber of Chinese National Standard 14631 (CNS 14631) (2002). Type B platform lumber indicates structural lumber used in platform construction but not generally used for applications that require high static bending properties. The lumber was classified into three grades, namely construction (C) grade lumber; standard (S) grade lumber; and utility (U) grade lumber. However, when the lumber did not meet the utility grade standard, it was classified as below (B)-grade lumber.

\subsection{Ultrasonic wave method}

The ultrasonic wave method was used to estimate the dynamic modulus of elasticity (DMOEv) of the lumber, using Sylvatest equipment (with a frequency of $22 \mathrm{kHz}$; Swiss Products). The ultrasonic wave method required the placement of two piezoelectric transducers (the transmitting and receiving transducers) in contact with opposite ends, and the ultrasonic wave velocity $(\mathrm{V})$ and DMOEv were calculated based on the following formulae,

$\mathrm{V}=\frac{\mathrm{L}}{\mathrm{T}}$ and

$\mathrm{DMOEv}=\mathrm{V}^{2} \rho$

where $\mathrm{V}$ is the ultrasonic wave velocity in the direction parallel to the grain of the lumber, $L$ the distance between the two transducers, $T$ the propagation time of the pulse from the transmitting transducer to the receiving transducer, DMOEv the dynamic modulus of elasticity in the direction parallel to the grain of lumber, and $\rho$ is the density based on the mass to volume ratio of the lumber.

\subsection{Transuerse vibration method}

The transverse vibration test was carried out using a Metriguard Model 340 Transverse Vibration Tester. The test lumber was supported at one end by a knife-edge support and at the opposite end by a load-cell transducer. The dimensions of the lumber were physically measured, and then the load-cell transducer that was interfaced with a computer automatically determined its weight and natural frequency. The DMOEt of the lumber was calculated by the following equation:

$\mathrm{DMOEt}=\frac{\mathrm{fr}^{2} \mathrm{WL}^{3}}{6.63 \mathrm{I}}$

where DMOEt is the modulus of elasticity determined by transverse vibration, fr the natural frequency $(\mathrm{Hz}), \mathrm{W}$ the weight of the lumber, $L$ the span of lumber between supports, and $I$ is the moment of inertia.

\subsection{Static bending}

To obtain the static bending properties of all specimens, the specimens were tested in accordance with ASTM D198 (the third-point loading method) (ASTM, 1996), using a Shimadzu (Japan) UH-10A universal-type testing machine. All of the lum- 
Table 1 - Analysis of multiple new-range Duncan's test of mechanical properties for visual grading

\begin{tabular}{|c|c|c|c|c|c|c|}
\hline Species & Parameters & Construction & Standard & Utility & Below grade & Tota \\
\hline \multirow{7}{*}{$\begin{array}{l}\text { Japanese } \\
\text { cedar }\end{array}$} & $\mathrm{N}$ & 38 & 29 & 27 & 104 & 198 \\
\hline & $\rho\left(\mathrm{kg} / \mathrm{m}^{3}\right)$ & $502 \mathrm{a}$ & $536 a$ & $510 \mathrm{a}$ & $491 \mathrm{~b}$ & 502 \\
\hline & $\mathrm{V}(\mathrm{m} / \mathrm{s})$ & 4911 a & $4683 a b$ & $4485 \mathrm{~b}$ & $4219 c$ & 4456 \\
\hline & DMOEv (GPa) & $12.1 \mathrm{a}$ & $11.9 a$ & $10.3 \mathrm{~b}$ & $8.8 \mathrm{c}$ & 10.1 \\
\hline & DMOEt (GPa) & $11.7 \mathrm{a}$ & $11.2 \mathrm{a}$ & $9.9 \mathrm{~b}$ & $8.1 \mathrm{c}$ & 9.5 \\
\hline & MOE (GPa) & $11.8 \mathrm{a}$ & $11.2 \mathrm{a}$ & $9.8 \mathrm{~b}$ & $8.0 \mathrm{c}$ & 9.4 \\
\hline & $\mathrm{MOR}^{*}(\mathrm{MPa})$ & 65 & 61 & 53 & 43 & 51 \\
\hline \multirow{7}{*}{ Taiwania } & $\mathrm{N}$ & 55 & 51 & 55 & 141 & 302 \\
\hline & $\rho\left(\mathrm{kg} / \mathrm{m}^{3}\right)$ & $425 a$ & $409 a$ & $421 \mathrm{a}$ & $415 \mathrm{a}$ & 417 \\
\hline & $\mathrm{V}(\mathrm{m} / \mathrm{s})$ & $5275 a$ & $5108 \mathrm{ab}$ & 5015 bc & $4833 \mathrm{c}$ & 4993 \\
\hline & DMOEv (GPa) & $11.9 \mathrm{a}$ & $10.8 \mathrm{~b}$ & $10.7 \mathrm{bc}$ & $9.8 \mathrm{c}$ & 10.5 \\
\hline & DMOEt (GPa) & $11.0 \mathrm{a}$ & $9.8 \mathrm{~b}$ & $9.6 \mathrm{bc}$ & $8.9 c$ & 9.6 \\
\hline & MOE (GPa) & $10.5 \mathrm{a}$ & $9.4 \mathrm{~b}$ & $9.1 \mathrm{bc}$ & $8.3 \mathrm{c}$ & 9.1 \\
\hline & MOR (MPa) & 52 & 47 & 46 & 42 & 45 \\
\hline \multirow{7}{*}{$\begin{array}{l}\text { Douglas } \\
\text { fir }\end{array}$} & $\mathrm{N}$ & 18 & 24 & 22 & 99 & 163 \\
\hline & $\rho\left(\mathrm{kg} / \mathrm{m}^{3}\right)$ & $552 \mathrm{a}$ & $532 \mathrm{a}$ & $531 \mathrm{a}$ & $506 \mathrm{~b}$ & 518 \\
\hline & $\mathrm{V}(\mathrm{m} / \mathrm{s})$ & 5433 a & 5389 a & $5140 \mathrm{~b}$ & $4958 \mathrm{~b}$ & 5099 \\
\hline & DMOEv (GPa) & $16.4 \mathrm{a}$ & $15.5 \mathrm{a}$ & $14.0 \mathrm{~b}$ & $12.5 \mathrm{c}$ & 13.6 \\
\hline & DMOEt (GPa) & $14.9 \mathrm{a}$ & $13.6 \mathrm{~b}$ & $12.5 \mathrm{c}$ & $11.1 \mathrm{~d}$ & 12.1 \\
\hline & MOE (GPa) & $15.6 \mathrm{a}$ & $13.8 \mathrm{~b}$ & $12.5 \mathrm{c}$ & $10.6 \mathrm{~d}$ & 11.9 \\
\hline & MOR (MPa) & 74 & 64 & 57 & 46 & 53 \\
\hline \multirow{7}{*}{$\begin{array}{l}\text { Southern } \\
\text { pine }\end{array}$} & $\mathrm{N}$ & 96 & 8 & 14 & 5 & 123 \\
\hline & $\rho\left(\mathrm{kg} / \mathrm{m}^{3}\right)$ & $622 \mathrm{a}$ & $624 \mathrm{a}$ & $625 a$ & $601 \mathrm{a}$ & 622 \\
\hline & $\mathrm{V}(\mathrm{m} / \mathrm{s})$ & $5134 \mathrm{a}$ & $5034 \mathrm{ab}$ & $4926 a b$ & $4669 \mathrm{~b}$ & 5085 \\
\hline & DMOEv (GPa) & $16.5 \mathrm{a}$ & $15.9 \mathrm{a}$ & $15.3 \mathrm{a}$ & $13.2 \mathrm{a}$ & 16.2 \\
\hline & DMOEt (GPa) & $15.4 \mathrm{a}$ & $15.0 \mathrm{a}$ & $14.3 \mathrm{a}$ & $12.2 \mathrm{a}$ & 15.1 \\
\hline & MOE (GPa) & $15.2 \mathrm{a}$ & $14.4 \mathrm{a}$ & $14.1 \mathrm{a}$ & $11.9 \mathrm{a}$ & 14.9 \\
\hline & MOR (MPa) & 73 & 70 & 68 & 58 & 72 \\
\hline
\end{tabular}

$\mathrm{N}$, number of samples; $\rho$, density; $\mathrm{V}$, ultrasonic wave velocity; DMOEv, dynamic modulus of elasticity using the ultrasonic wave method; DMOEt, dynamic modulus of elasticity using the transverse vibration method; MOE, modulus of elasticity; MOR, modulus of rupture.

* MOR was calculated from Refs. Wang and Ko (1998), Wang et al. (2005), Biblis et al. (2004) and Green et al. (2005). Values sharing the same letter do not significantly differ at the 0.05 level.

ber was subjected to flat loading for the bending tests. The span was $150 \mathrm{~cm}$, the distance between the two loading points was $50 \mathrm{~cm}$. The proportional limit, ultimate load, and deflection were obtained from load-deflection curves, and the static modulus of elasticity (MOE) was calculated by the following formula:

$\mathrm{MOE}=\frac{P^{\prime} a\left(3 L^{2}-4 a^{2}\right)}{48 \delta I} ;$

where $\mathrm{P}^{\prime}$ is the load at proportional limit, $a$ the distance from the end support to the nearest load point $(a=L / 3), L$ the span of lumber between supports, $\delta$ the midspan deflection and I is the moment of inertia.

Because all lumber required further processing and utilization, no failure (breaking) tests were included in this study. Values for the modulus of rupture (MOR) were calculated from appropriate Refs. (Japanese cedar (Wang and Ko, 1998), Taiwania (Wang et al., 2005), Southern pine (Biblis et al., 2004), and Douglas fir (Green et al., 2005)).

\subsection{Mechanical stress grading}

The MOE and MOR data for each piece were used to sort the lumber into machine-stress-rated (MSR) categories. Chinese National Standard (CNS 14633) (2002) rules allow sorting into any design bending strength $\left(F_{b}\right)$ and modulus of elasticity $(E)$ combination. The MSR categories were compiled according to Chinese National Standard (CNS) rules, which include the following requirements:(1) the average MOE for a grade group must be equal to or greater than the assigned E; (2) $95 \%$ of the specimens must have an MOE greater than $82 \%$ of the assigned $E$ value (the minimum MOE value); (3) and $95 \%$ of the pieces must have an MOR of greater than 2.1 times the assigned $F_{b}$ (the minimum MOR value).

\section{Results and discussion}

\subsection{The frequency of visually graded lumber}

The number of graded specimens and the frequencies of the different visually graded lumber are shown in Table 1 and Fig. 1. Low frequencies (11.0-19.2\%) for the construction grade (C), standard grade (S), and utility grade (U) were found for Japanese cedar, Taiwania and Douglas fir, but high frequencies (47.6-60.7\%) were found for the below-grade (B) lumber. However, a high frequency $(78.0 \%)$ in $C$ lumber was found for Southern pine, and low frequencies (4.1-11.4\%) for S, U and B lumber. Therefore, the Southern pine lumber had a higher visual grading yield than that of Japanese cedar, Taiwania and Douglas fir. 


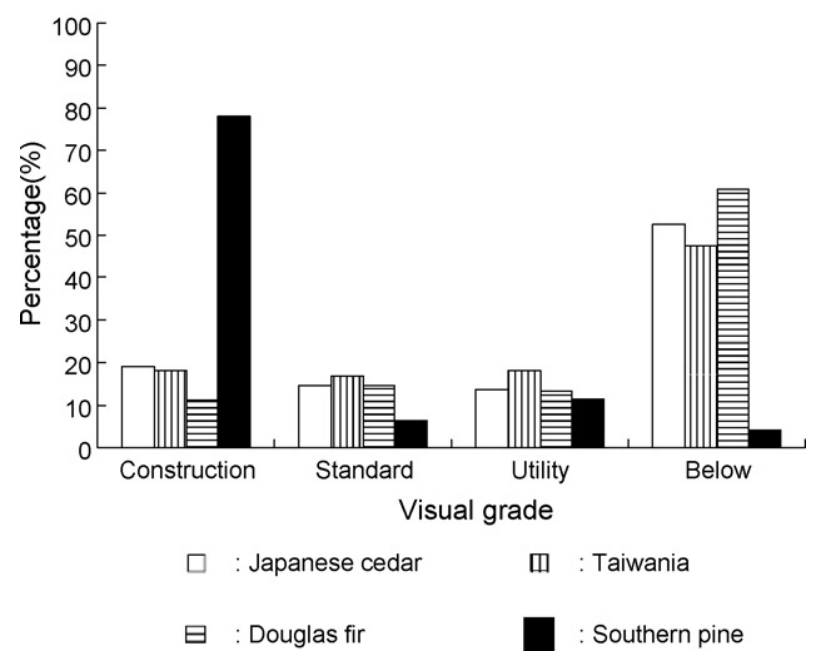

Fig. 1 - The frequency of different visually graded lumber specimens.

In this study, the greatest number of defects occurring in the four softwood lumbers was knots, while other defects such as stains, decay, wanes, crooks, warps, pitting and twists were few. The knot types included both loose (about 25\%) and tight (about 75\%) knots. Hence, knots were the most important factor in judging the lumber grades by visual grading. This is because the lumber cut from small-diameter Japanese cedar and Taiwania plantation trees includes many knots (number and size) in Taiwan.

\subsection{Effects of lumber visual grades on mechanical properties}

Differences in the $\rho, \mathrm{V}$, DMOEv, DMOEt and MOE among different visual grades were analyzed using the multiple new-range Duncan test. The results are shown in Table 1.

For lumber graded visually according to the CNS 14631 standard, significant differences (at the $P<0.05$ level) in wood density $(\rho)$ values between grades $U$ and B were only observed for the Japanese cedar and Douglas fir lumber. However, there were no significant differences among other various grades of lumber.

The average ultrasonic wave velocity (V) values of the four grades of lumber in decreasing order were construction grade (C) > standard grade (S) > utility grade (U) > below grade (B) from all four species. For Japanese cedar lumber, the $V$ values of grades C, $S$ and U lumber were significantly greater than that of grade $B$ lumber, and there was a significant difference between grades $C$ and $U$. For Taiwania lumber, the $V$ values of grades $C$ and $S$ lumber were significantly greater than that of grade $B$ lumber, and there was a significant difference between grades $C$ and U. For Douglas fir lumber, the $V$ values of grades $C$ and $S$ lumber were significantly greater than those of grades $U$ and $B$ lumber. For Southern pine lumber, the $V$ value of grade $C$ lumber was significantly greater than that of grade $B$ lumber. No significant differences in $V$ values among the other grades of lumber were observed in the four species.

The average DMOEv values of different grades of lumber in decreasing order were construction grade $(C)>$ standard grade
(S) > utility grade $(\mathrm{U})>$ below grade $(\mathrm{B})$. However, there were no significant differences between grades $C$ and $S$ in Japanese cedar and Douglas fir lumber. For Taiwania lumber, there were no significant differences between grades $\mathrm{S}$ and $\mathrm{U}$, and grades $\mathrm{U}$ and B. Moreover, no significant differences in DMOEv values among grades $\mathrm{C}, \mathrm{S}, \mathrm{U}$ and $\mathrm{B}$ were observed for Southern pine lumber. The results of DMOEv values among different visual grades were similar to the DMOEt and MOE values of Japanese cedar, Taiwania and Southern pine lumber. However, for Douglas fir lumber, significant differences in the DMOEt and MOE values among grades S, C, U and B lumber were observed.

Similar results were also reported in a study carried out by Wang and Lin (1996) where Japanese cedar lumber was classified into special grades of 1, 2 and 3 according to the Japan Agricultural Standard (JAS). This study showed that the average DMOE, MOE and MOR values of visually graded special-grade lumber were significantly greater than those of the second- and third-grade groups. The results are also consistent with two previous studies (Wang and Ko, 1998; Wang et al., 2005). In one of these studies revealed that the better-grades of Taiwania lumber had high MOE values, and the similar tendency was also shown in the relationship between lumber grades and dynamic MOE values (Wang et al., 2005).

The above-mentioned results reveal that the better grades of lumber had higher DMOEv, DMOEt and MOE values. However, a part of the results showed no statistically significant differences among different visual grades. When the lumber used in the study was graded according to normal Taiwan visual grading rules, it generally incompletely met the normal bending properties requirements. Therefore, the visual grading rules employed by CNS 14631 are not very sensitive for grading plantation lumber due to the small differences in bending characteristics among grades, as the major parameters, such as knots and juvenile wood. Therefore bending properties of the samples might not be thoroughly understood. It is fact that mechanical properties of wood are significantly influenced by amount of defects.

\subsection{The frequency and mechanical properties of MSR-graded lumber}

The lumber specimens were graded by a MSR according to the CNS 14633 standard. The number of graded specimens and the frequencies of different MSR-grades of lumber are shown in Table 2 .

In this study, specimens were classified into below, $900 F_{b}-1.0 E, \quad 1200 F_{b}-1.2 E, \quad 1650 F_{b}-1.3 E, \quad 1650 F_{b}-1.4 E$, $1950 F_{b}-1.5 E, \quad 2100 F_{b}-1.8 E, \quad 2250 F_{b}-1.6 E, \quad 2250 F_{b}-1.9 E$, $2400 F_{b}-1.7 E, \quad 2400 F_{b}-2.0 E, \quad 2550 F_{b}-2.1 E, \quad 2700 F_{b}-2.2 E$, $2850 F_{b}-2.3 E, 3000 F_{b}-2.4 E, 3150 F_{b}-2.5 E$ and $3300 F_{b}-2.6 E$ categories. The MSR grades of the Japanese cedar, Taiwania, Douglas fir and Southern pine lumber ranged from below to $2850 F_{b}-2.3 E$, below to $3150 F_{b}-2.5 E$, below to $3300 F_{b}-2.6 E$, and $900 F_{b}-1.0 E$ to $3300 F_{b}-2.6 E$, respectively. The highest frequencies $(23.2 \%, 29.3 \%, 14.0 \%$, and $21.5 \%)$ in $900 F_{b}-1.0 E$, $900 F_{b}-1.0 E, 1950 F_{b}-1.5 E$ and $3300 F_{b}-2.6 E$ categories were found in MSR grades of Japanese cedar, Taiwania, Douglas fir and Southern pine lumber, respectively. A considerable portion of the southern pine lumber had mechanical prop- 
Table 2 - Mechanical properties for machine-stress-rated (MSR) grading

\begin{tabular}{|c|c|c|c|c|c|c|c|c|}
\hline Species & MSR grade & $\mathrm{N}$ & $\rho\left(\mathrm{kg} / \mathrm{m}^{3}\right)$ & $\mathrm{V}(\mathrm{m} / \mathrm{s})$ & DMOEv (GPa) & DMOEt (GPa) & MOE (GPa) & MOR (MPa) \\
\hline \multirow{14}{*}{$\begin{array}{l}\text { Japanese } \\
\text { cedar }\end{array}$} & Below & 24 [12.1] & 472 & 3793 & 6.8 & 6.0 & 6.0 & 31 \\
\hline & $900 F_{b}-1.0 E$ & 46 [23.2] & 470 & 4210 & 8.3 & 7.6 & 7.6 & 40 \\
\hline & $1200 F_{b}-1.2 E$ & 20 [10.1] & 492 & 4247 & 8.9 & 8.5 & 8.6 & 46 \\
\hline & $1650 F_{b}-1.3 E$ & 22 [11.1] & 478 & 4601 & 10.1 & 9.3 & 9.3 & 50 \\
\hline & $1650 F_{b}-1.4 E$ & 18 [9.1] & 493 & 4767 & 11.2 & 10.3 & 10.0 & 54 \\
\hline & $1950 F_{b}-1.5 E$ & 17 [8.6] & 520 & 4749 & 11.7 & 11.3 & 10.6 & 58 \\
\hline & $2100 F_{b}-1.8 E$ & 8 [9.0] & 559 & 4713 & 12.4 & 12.3 & 12.7 & 70 \\
\hline & $2250 F_{b}-1.6 E$ & $16[8.1]$ & 554 & 4642 & 11.9 & 11.5 & 11.4 & 63 \\
\hline & $2250 F_{b}-1.9 E$ & $6[3.0]$ & 556 & 5027 & 14.0 & 13.5 & 13.5 & 75 \\
\hline & $2400 F_{b}-1.7 E$ & 13 [6.6] & 542 & 4827 & 12.6 & 11.9 & 12.0 & 66 \\
\hline & $2400 F_{b}-2.0 E$ & $5[2.5]$ & 591 & 4976 & 14.6 & 14.2 & 14.2 & 79 \\
\hline & $2550 F_{b}-2.1 E$ & $1[0.5]$ & 563 & 5063 & 14.4 & 13.1 & 15.0 & 84 \\
\hline & $2700 F_{b}-2.2 E$ & $1[0.5]$ & 588 & 4942 & 14.4 & 14.5 & 15.5 & 87 \\
\hline & $2850 F_{b}-2.3 E$ & $1[0.5]$ & 586 & 5113 & 15.3 & 16.3 & 16.4 & 92 \\
\hline \multirow{8}{*}{ Total } & & 198 & 533 & 4690 & 11.9 & 11.5 & 11.6 & 63 \\
\hline & Below & 36 [13.5] & 390 & 4395 & 7.6 & 7.0 & 6.3 & 33 \\
\hline & $900 F_{b}-1.0 E$ & 78 [29.3] & 405 & 4731 & 9.1 & 8.2 & 7.6 & 39 \\
\hline & $1200 F_{b}-1.2 E$ & 50 [18.8] & 417 & 4943 & 10.2 & 9.1 & 8.6 & 43 \\
\hline & $1650 F_{b}-1.3 E$ & 35 [13.2] & 419 & 5140 & 11.1 & 9.8 & 9.3 & 46 \\
\hline & $1650 F_{b}-1.4 E$ & 33 [12.4] & 426 & 5276 & 11.9 & 10.5 & 10.0 & 49 \\
\hline & $1950 F_{b}-1.5 E$ & 31 [11.7] & 427 & 5331 & 12.1 & 11.2 & 10.7 & 53 \\
\hline & $2100 F_{b}-1.8 E$ & 9 [3.4] & 444 & 5520 & 13.5 & 12.5 & 12.7 & 61 \\
\hline \multirow[t]{8}{*}{ Taiwania } & $2250 F_{b}-1.6 E$ & 14 [5.3] & 443 & 5323 & 12.5 & 11.6 & 11.4 & 56 \\
\hline & $2250 F_{b}-1.9 E$ & $2[0.8]$ & 448 & 5142 & 11.8 & 13.0 & 13.2 & 63 \\
\hline & $2400 F_{b}-1.7 E$ & 5 [1.9] & 442 & 5425 & 13.0 & 12.2 & 12.2 & 59 \\
\hline & $2400 F_{b}-2.0 E$ & $2[0.8]$ & 462 & 5457 & 13.8 & 14.3 & 14.4 & 69 \\
\hline & $2550 F_{b}-2.1 E$ & 3 [1.1] & 442 & 5801 & 15.0 & 15.1 & 14.8 & 71 \\
\hline & $2700 F_{b}-2.2 E$ & $2[0.8]$ & 453 & 5602 & 14.1 & 16.3 & 15.6 & 74 \\
\hline & $2850 F_{b}-2.3 E$ & $1[0.4]$ & 496 & 5607 & 15.6 & 16.3 & 16.7 & 77 \\
\hline & $3150 F_{b}-2.5 E$ & $1[0.4]$ & 547 & 5571 & 17.0 & 18.5 & 17.8 & 84 \\
\hline \multirow[t]{8}{*}{ Total } & & 266 & 447 & 5347 & 12.9 & 12.8 & 12.5 & 60 \\
\hline & Below & $1[0.6]$ & 469 & 3780 & 6.7 & 6.5 & 5.8 & 20 \\
\hline & $900 F_{b}-1.0 E$ & 5 [3.2] & 477 & 4484 & 9.6 & 8.8 & 7.8 & 31 \\
\hline & $1200 F_{b}-1.2 E$ & $11[7.0]$ & 480 & 4734 & 10.8 & 9.5 & 8.6 & 35 \\
\hline & $1650 F_{b}-1.3 E$ & $12[7.6]$ & 482 & 4847 & 11.3 & 10.1 & 9.3 & 39 \\
\hline & $1650 F_{b}-1.4 E$ & 15 [9.6] & 482 & 5029 & 12.3 & 10.8 & 10.0 & 43 \\
\hline & $1950 F b-1.5 E$ & 22 [14.0] & 512 & 4951 & 12.5 & 11.2 & 10.7 & 47 \\
\hline & $2100 F_{b}-1.8 E$ & 13 [8.3] & 537 & 5176 & 14.4 & 12.7 & 12.8 & 58 \\
\hline Douglas & $2250 F_{b}-1.6 E$ & 17 [10.8] & 524 & 5027 & 13.2 & 11.8 & 11.3 & 50 \\
\hline \multirow[t]{8}{*}{ fir } & $2250 F_{b}-1.9 E$ & 17 [10.8] & 525 & 5347 & 15.0 & 13.4 & 13.4 & 62 \\
\hline & $2400 F_{b}-1.7 E$ & 20 [12.7] & 533 & 5120 & 14.0 & 12.3 & 12.1 & 54 \\
\hline & $2400 F_{b}-2.0 E$ & $10[6.4]$ & 553 & 5334 & 15.7 & 13.6 & 14.2 & 66 \\
\hline & $2550 F_{b}-2.1 E$ & $8[5.1]$ & 543 & 5428 & 16.0 & 14.1 & 14.8 & 69 \\
\hline & $2700 F_{b}-2.2 E$ & $4[2.5]$ & 530 & 5525 & 16.2 & 14.1 & 15.4 & 73 \\
\hline & $2850 F_{b}-2.3 E$ & $1[0.6]$ & 541 & 5465 & 16.2 & 14.1 & 16.0 & 76 \\
\hline & $3150 F_{b}-2.5 E$ & 2 [1.3] & 526 & 5749 & 17.4 & 16.0 & 17.5 & 84 \\
\hline & $3300 F_{b}-2.6 E$ & $5[3.2]$ & 599 & 5684 & 19.3 & 17.5 & 19.6 & 96 \\
\hline \multirow[t]{8}{*}{ Total } & & 157 & 526 & 5244 & 14.6 & 12.9 & 13.3 & 60 \\
\hline & $900 F_{b}-1.0 E$ & $1[0.8]$ & 619 & 3744 & 8.7 & 8.0 & 7.4 & 36 \\
\hline & $1200 F_{b}-1.2 E$ & $1[0.8]$ & 584 & 4288 & 10.7 & 9.9 & 8.8 & 43 \\
\hline & $1650 F_{b}-1.3 E$ & $3[2.5]$ & 544 & 4460 & 10.8 & 10.1 & 9.2 & 45 \\
\hline & $1650 F_{b}-1.4 E$ & $6[5.0]$ & 592 & 4534 & 12.1 & 10.9 & 10.1 & 49 \\
\hline & $1950 F_{b}-1.5 E$ & 5 [4.1] & 531 & 4843 & 12.4 & 11.4 & 10.7 & 52 \\
\hline & $2100 F_{b}-1.8 E$ & 9 [7.4] & 600 & 4858 & 14.2 & 13.3 & 12.7 & 62 \\
\hline & $2250 F_{b}-1.6 E$ & $7[5.8]$ & 563 & 4886 & 13.4 & 12.2 & 11.4 & 56 \\
\hline \multirow{4}{*}{$\begin{array}{l}\text { Southern } \\
\text { pine }\end{array}$} & $2250 F_{b}-1.9 E$ & 13 [10.7] & 606 & 4974 & 14.9 & 14.0 & 13.4 & 65 \\
\hline & $2400 F_{b}-1.7 E$ & $4[3.3]$ & 637 & 4691 & 13.9 & 13.1 & 12.2 & 59 \\
\hline & $2400 F_{b}-2.0 E$ & 10 [8.3] & 606 & 5124 & 15.9 & 14.9 & 14.2 & 69 \\
\hline & $2550 F_{b}-2.1 E$ & 10 [8.3] & 624 & 5113 & 16.3 & 15.2 & 14.8 & 72 \\
\hline
\end{tabular}




\begin{tabular}{|c|c|c|c|c|c|c|c|c|}
\hline Species & MSR grade & N & $\rho\left(\mathrm{kg} / \mathrm{m}^{3}\right)$ & $\mathrm{V}(\mathrm{m} / \mathrm{s})$ & DMOEv (GPa) & DMOEt (GPa) & MOE (GPa) & MOR (MPa) \\
\hline & $2700 F_{b}-2.2 E$ & $7[5.8]$ & 593 & 5245 & 16.3 & 15.5 & 15.4 & 75 \\
\hline & $2850 F_{b}-2.3 E$ & $7[5.8]$ & 669 & 5212 & 18.2 & 17.1 & 16.3 & 79 \\
\hline & $3000 F_{b}-2.4 E$ & $7[5.8]$ & 639 & 5375 & 18.5 & 17.0 & 17.0 & 82 \\
\hline & $3150 F_{b}-2.5 E$ & $7[5.8]$ & 660 & 5284 & 18.3 & 17.0 & 17.5 & 84 \\
\hline & $3300 F_{b}-2.6 E$ & 26 [21.5] & 671 & 5425 & 19.7 & 18.6 & 19.2 & 92 \\
\hline Total & & 121 & 609 & 5001 & 15.3 & 14.3 & 13.9 & 67 \\
\hline
\end{tabular}

erties high enough to be graded as MSR lumber. Therefore, Southern pine lumber had higher MSR grade yields than Japanese cedar, Taiwania and Douglas fir in this experiment.

\subsection{The frequency of visually graded lumbers in the MSR categories}

The lumber specimens were graded visually according to the CNS 14631 standard, then the CNS 14633 criteria were used for the MSR grading. The frequencies of the four visually grades of lumbers in different MSR-graded lumber are shown in Table 3. As shown in Table 3, the better visually graded lumber (construction grade) had higher mechanical properties and higher frequencies existed in the stronger MSR categories. On the contrary, the poorer visually graded lumbers (below grade) had lower mechanical properties and higher frequencies existed in the weaker MSR categories.

However, a portion of the results showed that lower frequencies of better visual grades existed in weaker MSR categories, and poorer visual grades existed in stronger MSR categories. Therefore, it was concluded that mechanical grading was more reliable and more efficient than visual grading.

\subsection{Effect of density on mechanical properties}

Wood density is an important factor influencing overall strength properties of wood. Values of the MOE of four species used in this work increased with increasing wood density. Their relationships can be represented by the positive linear regression formulae shown in Table 4. It was also found that the coefficient of determination $\left(R^{2}\right)$ values were $0.28-0.33$, 0.24-0.31, 0.34-0.42 and 0.31-0.38 for Japanese cedar, Taiwania, Douglas fir, and Southern pine, respectively. Although these results were significant at the 0.01 confidence level, the $R^{2}$ values of the regression analysis were not high.

These smaller $R^{2}$ values of the above linear regression formulae were also reported earlier by Lin et al. (1992), whose data were obtained from small-diameter logs of Japanese cedar and China-fir. Wang and Chen (1990) also reported an $r$ value of 0.66 for the relationship between specific gravity and MOR of China-fir. A similar result was also obtained by Wang and Lin (1996), who pointed out that the $R^{2}$ values for the linear regression formula between density and DMOE and MOE for Japanese cedar were 0.50 and 0.31 , respectively. Burdzik and Nkwera (2002) also indicated that density was not a particularly good predictor for accurately predicting the MOE and MOR. The higher $R^{2}$ values $(0.49-0.86$, Table 5$)$ were found in this experiment when the MOEv/ $\rho$, DMOEv/ $\rho$, and
$\mathrm{MOE} / \rho$ (specific MOE) were used as predictors to evaluate the MOE.

\subsection{Correlations among the three mechanical properties}

It was found that the DMOEv, DMOEt and MOE values showed the following trend: DMOEv > DMOEt > MOE. Furthermore, statistical analysis showed that the DMOEv value, which was determined by the transmission velocity of ultrasonic waves, was higher than the values of DMOEt and MOE for all species. In this study the mean values of DMOEv were greater than those of DMOEt by $6.4 \%, 9.9 \%, 12.6 \%$ and $7.1 \%$ for Japanese cedar, Taiwania, Douglas fir and Southern pine, respectively. It was also greater than those of the static MOE by $7.1 \%, 16.1 \%$, $14.2 \%$ and $9.0 \%$ for the same respective species. These results are similar to those obtained by Haines and Leban (1997) and below those of the studies by Sinclair and Farshad (1987) and Haines et al. (1996) who reported that the mean value of Young's modulus from the longitudinal ultrasonic method exceeded the MOE by about $17-22 \%$.

In comparison to the DMOEv of lumber, the DMOEt of lumber was much closer to the MOE. The values of DMOEt were only $0.7 \%, 5.7 \%, 1.4 \%$ and $1.8 \%$ greater than those of $\mathrm{MOE}$ for Japanese cedar, Taiwania, Douglas fir and Southern pine, respectively. In other words, values of the DMOEv were higher than those of both the DMOEt and MOE which were close to each other.

This result is in agreement with a previous report by Wang et al. (2002) who selected jack pine and red pine for testing using stress-wave transmission speed, transverse vibration and static bending methods. They found that the DMOE, which had been determined by the stress wave transmission speed test, was higher than the DMOEt, which had been determined by transverse vibration and the MOE. In the case of jack pine, the DMOE was $24.7 \%$ higher than the DMOEt and $21.6 \%$ higher than the MOE, while for red pine, the DMOE was $18.8 \%$ higher than the DMOEt and 21.6\% higher than the MOE. Overall, the DMOEt and MOE were close to each other, with the DMOEt about 7\% higher than the MOE. Burdzik and Nkwera (2002) pointed out that the DMOEt was around 5\% higher than the MOE.

Statistical correlation analyzed by linear regression was used to examine the relationship between the static and dynamic MOE measurements which are presented in Table 6.

In general, not only was the dynamic MOE (DMOEv and DMOEt) usually higher than the static MOE, but it also had a close relationship with the MOE. Hence, it could be used 
Table 3 - Frequency of different visual grades of lumber in different machine-stress-rating (MSR) grades of dimension

lumber

\begin{tabular}{|c|c|c|c|c|c|c|}
\hline \multirow[t]{2}{*}{ Species } & \multirow[t]{2}{*}{ MSR grade } & \multicolumn{5}{|c|}{ Visual grade } \\
\hline & & Construction & Standard & Utility & Below & Total \\
\hline \multirow{14}{*}{$\begin{array}{l}\text { Japanese } \\
\text { cedar }\end{array}$} & Below & $0(0)$ & $0(0)$ & $0(0)$ & $24(100)$ & 24 \\
\hline & $900 F_{b}-1.0 E$ & $0(0)$ & $2(4)$ & $4(9)$ & $40(87)$ & 46 \\
\hline & $1200 F_{b}-1.2 E$ & $1(5)$ & $4(20)$ & $4(20)$ & $11(55)$ & 20 \\
\hline & $1650 F_{b}-1.3 E$ & $3(14)$ & $1(5)$ & $5(23)$ & $13(59)$ & 22 \\
\hline & $1650 F_{b}-1.4 E$ & $6(33)$ & $2(11)$ & $3(17)$ & 7 (39) & 18 \\
\hline & $1950 F_{b}-1.5 E$ & $6(35)$ & $2(12)$ & $5(29)$ & $4(24)$ & 17 \\
\hline & $2100 F_{b}-1.8 E$ & $3(38)$ & $4(50)$ & $0(0)$ & $1(13)$ & 8 \\
\hline & $2250 F_{b}-1.6 E$ & $4(25)$ & $5(31)$ & $4(25)$ & $3(19)$ & 16 \\
\hline & $2250 F_{b}-1.9 E$ & $4(67)$ & $2(33)$ & $0(0)$ & $0(0)$ & 6 \\
\hline & $2400 F_{b}-1.7 E$ & $5(38)$ & $5(38)$ & $2(15)$ & $1(8)$ & 13 \\
\hline & $2400 F_{b}-2.0 E$ & $3(60)$ & $2(40)$ & $0(0)$ & $0(0)$ & 5 \\
\hline & $2550 F_{b}-2.1 E$ & $1(100)$ & $0(0)$ & $0(0)$ & $0(0)$ & 1 \\
\hline & $2700 F_{b}-2.2 E$ & $1(100)$ & $0(0)$ & $0(0)$ & $0(0)$ & 1 \\
\hline & $2850 F_{b}-2.3 E$ & $1(100)$ & $0(0)$ & $0(0)$ & $0(0)$ & 1 \\
\hline \multirow[t]{8}{*}{ Total } & & 38 & 29 & 27 & 104 & 198 \\
\hline & Below & $2(6)$ & $3(8)$ & $4(11)$ & $27(75)$ & 36 \\
\hline & $900 F_{b}-1.0 E$ & 7 (9) & $15(19)$ & $14(18)$ & $42(54)$ & 78 \\
\hline & $1200 F_{b}-1.2 E$ & $6(12)$ & $7(14)$ & $8(16)$ & $29(58)$ & 50 \\
\hline & $1650 F_{b}-1.3 E$ & $9(26)$ & $3(9)$ & $5(14)$ & $18(51)$ & 35 \\
\hline & $1650 F_{b}-1.4 E$ & $7(21)$ & $5(15)$ & $11(33)$ & $10(30)$ & 33 \\
\hline & $1950 F_{b}-1.5 E$ & $6(19)$ & $10(32)$ & $5(16)$ & $10(32)$ & 31 \\
\hline & $2100 F_{b}-1.8 E$ & $2(22)$ & $4(44)$ & $1(11)$ & $2(22)$ & 9 \\
\hline \multirow[t]{8}{*}{ Taiwania } & $2250 F_{b}-1.6 E$ & $4(29)$ & $3(21)$ & $6(43)$ & $1(7)$ & 14 \\
\hline & $2250 F_{b}-1.9 E$ & $2(100)$ & $0(0)$ & $0(0)$ & $0(0)$ & 2 \\
\hline & $2400 F_{b}-1.7 E$ & $1(20)$ & $1(20)$ & $1(20)$ & $2(40)$ & 5 \\
\hline & $2400 F_{b}-2.0 E$ & $2(100)$ & $0(0)$ & $0(0)$ & $0(0)$ & 2 \\
\hline & $2550 F_{b}-2.1 E$ & $3(100)$ & $0(0)$ & $0(0)$ & $0(0)$ & 3 \\
\hline & $2700 F_{b}-2.2 E$ & $2(100)$ & $0(0)$ & $0(0)$ & $0(0)$ & 2 \\
\hline & $2850 F_{b}-2.3 E$ & $1(100)$ & $0(0)$ & $0(0)$ & $0(0)$ & 1 \\
\hline & $3150 F_{b}-2.5 E$ & $1(100)$ & $0(0)$ & $0(0)$ & $0(0)$ & 1 \\
\hline \multirow[t]{8}{*}{ Total } & & 55 & 51 & 55 & 141 & 302 \\
\hline & Below & $0(0)$ & $0(0)$ & $0(0)$ & $1(100)$ & 1 \\
\hline & $900 F_{b}-1.0 E$ & $0(0)$ & $0(0)$ & $0(0)$ & $5(100)$ & 5 \\
\hline & $1200 F_{b}-1.2 E$ & $0(0)$ & $0(0)$ & $0(0)$ & $11(100)$ & 11 \\
\hline & $1650 F_{b}-1.3 E$ & $0(0)$ & $0(0)$ & $0(0)$ & $12(100)$ & 12 \\
\hline & $1650 F_{b}-1.4 E$ & $0(0)$ & $0(0)$ & $3(20)$ & $12(80)$ & 15 \\
\hline & $1950 F_{b}-1.5 E$ & $1(5)$ & $1(5)$ & $1(5)$ & $19(86)$ & 22 \\
\hline & $2100 F_{b}-1.8 E$ & $1(8)$ & $2(15)$ & $6(46)$ & $4(31)$ & 13 \\
\hline \multirow{9}{*}{$\begin{array}{l}\text { Douglas } \\
\text { fir }\end{array}$} & $2250 F_{b}-1.6 E$ & $0(0)$ & $2(12)$ & $2(12)$ & $13(76)$ & 17 \\
\hline & $2250 F_{b}-1.9 E$ & $4(24)$ & $3(18)$ & $5(29)$ & $5(29)$ & 17 \\
\hline & $2400 F_{b}-1.7 E$ & $1(5)$ & $2(10)$ & $2(10)$ & $15(75)$ & 20 \\
\hline & $2400 F_{b}-2.0 E$ & $1(10)$ & $5(50)$ & $3(30)$ & $1(10)$ & 10 \\
\hline & $2550 F_{b}-2.1 E$ & $1(13)$ & $6(75)$ & $0(0)$ & $1(13)$ & 8 \\
\hline & $2700 F_{b}-2.2 E$ & $3(75)$ & $1(25)$ & $0(0)$ & $0(0)$ & 4 \\
\hline & $2850 F_{b}-2.3 E$ & $0(0)$ & $1(100)$ & $0(0)$ & $0(0)$ & 1 \\
\hline & $3150 F_{b}-2.5 E$ & $1(50)$ & $1(50)$ & $0(0)$ & $0(0)$ & 2 \\
\hline & $3300 F_{b}-2.6 E$ & $5(100)$ & $0(0)$ & $0(0)$ & $0(0)$ & 5 \\
\hline \multirow[t]{8}{*}{ Total } & & 18 & 24 & 22 & 99 & 163 \\
\hline & $900 F_{b}-1.0 E$ & $0(0)$ & $0(0)$ & $1(100)$ & $0(0)$ & 1 \\
\hline & $1200 F_{b}-1.2 E$ & $1(100)$ & $0(0)$ & $0(0)$ & $0(0)$ & 1 \\
\hline & $1650 F_{b}-1.3 E$ & $2(67)$ & $0(0)$ & $1(33)$ & $0(0)$ & 3 \\
\hline & $1650 F_{b}-1.4 E$ & $4(67)$ & $0(0)$ & $1(17)$ & $1(17)$ & 6 \\
\hline & $1950 F_{b}-1.5 E$ & $3(60)$ & $2(40)$ & $0(0)$ & $0(0)$ & 5 \\
\hline & $2100 F_{b}-1.8 E$ & $7(78)$ & $0(0)$ & $0(0)$ & $2(22)$ & 9 \\
\hline & $2250 F_{b}-1.6 E$ & $6(86)$ & $0(0)$ & $0(0)$ & $1(14)$ & 7 \\
\hline \multirow{2}{*}{$\begin{array}{l}\text { Southern } \\
\text { pine }\end{array}$} & $2250 F_{b}-1.9 E$ & $10(77)$ & $1(8)$ & $2(15)$ & $0(0)$ & 13 \\
\hline & $2400 F_{b}-1.7 E$ & $3(75)$ & $0(0)$ & $0(0)$ & $1(25)$ & 4 \\
\hline
\end{tabular}


Table 3 (Continued)

\begin{tabular}{|c|c|c|c|c|c|c|}
\hline \multirow[t]{2}{*}{ Species } & \multirow[t]{2}{*}{ MSR grade } & \multicolumn{5}{|c|}{ Visual grade } \\
\hline & & Construction & Standard & Utility & Below & Total \\
\hline & $2400 F_{b}-2.0 E$ & $7(70)$ & $1(10)$ & $2(20)$ & $0(0)$ & 10 \\
\hline & $2550 F_{b}-2.1 E$ & $7(70)$ & $0(0)$ & $3(30)$ & $0(0)$ & 10 \\
\hline & $2700 F_{b}-2.2 E$ & $5(71)$ & $2(29)$ & $0(0)$ & $0(0)$ & 7 \\
\hline & $2850 F_{b}-2.3 E$ & $5(71)$ & 1 (14) & 1 (14) & $0(0)$ & 7 \\
\hline & $3000 F_{b}-2.4 E$ & $7(100)$ & $0(0)$ & $0(0)$ & $0(0)$ & 7 \\
\hline & $3150 F_{b}-2.5 E$ & $6(86)$ & $0(0)$ & $1(14)$ & $0(0)$ & 7 \\
\hline & $3300 F_{b}-2.6 E$ & $23(88)$ & $1(4)$ & $2(8)$ & $0(0)$ & 26 \\
\hline Total & & 96 & 8 & 14 & 5 & 123 \\
\hline
\end{tabular}

For codes, see Table 1.

Table 4 - Correlations among density $(\rho)$, DMOEv, DMOEt, and MOE, analyzed by linear regression $(Y=A X+B)$ formulae for dimension lumber

\begin{tabular}{|c|c|c|c|c|c|c|}
\hline \multirow[t]{2}{*}{ Species } & \multicolumn{4}{|c|}{ Linear regression model $Y=A X+B$} & \multirow[t]{2}{*}{$R^{2}$} & \multirow[t]{2}{*}{ F-values } \\
\hline & Y & $X$ & A & B & & \\
\hline \multirow{3}{*}{$\begin{array}{l}\text { Japanese } \\
\text { cedar }\end{array}$} & DMOEv & $\rho$ & 0.0235 & -1.691 & 0.33 & $96^{* *}$ \\
\hline & DMOEt & $\rho$ & 0.0226 & -1.870 & 0.33 & $98^{* *}$ \\
\hline & MOE & $\rho$ & 0.0197 & -0.471 & 0.28 & $76^{* *}$ \\
\hline \multirow{3}{*}{ Taiwania } & DMOEv & $\rho$ & 0.0377 & -3.990 & 0.31 & $136^{* *}$ \\
\hline & DMOEt & $\rho$ & 0.0295 & -2.752 & 0.28 & $114^{* *}$ \\
\hline & MOE & $\rho$ & 0.0289 & -3.000 & 0.24 & $95^{* *}$ \\
\hline \multirow{3}{*}{$\begin{array}{l}\text { Douglas } \\
\text { fir }\end{array}$} & DMOEv & $\rho$ & 0.0352 & -4.702 & 0.42 & $119^{* *}$ \\
\hline & DMOEt & $\rho$ & 0.0277 & -2.300 & 0.34 & $82^{* *}$ \\
\hline & MOE & $\rho$ & 0.0342 & -5.868 & 0.34 & $83^{* *}$ \\
\hline \multirow{3}{*}{$\begin{array}{l}\text { Southern } \\
\text { pine }\end{array}$} & DMOEv & $\rho$ & 0.0293 & -2.009 & 0.38 & $75^{* *}$ \\
\hline & DMOEt & $\rho$ & 0.0256 & -0.777 & 0.33 & $61^{*}$ \\
\hline & MOE & $\rho$ & 0.0272 & -2.043 & 0.31 & $53^{* *}$ \\
\hline
\end{tabular}

Table 5 - Correlations among, DMOEv/ $\rho$, DMOEt $/ \rho$, MOE/ $\rho$ and MOE, analyzed by linear regression $(Y=A X+B)$ formulae for dimension lumber

\begin{tabular}{|c|c|c|c|c|c|c|}
\hline \multirow[t]{2}{*}{ Species } & \multicolumn{4}{|c|}{ Linear regression model $Y=A X+B$} & \multirow[t]{2}{*}{$R^{2}$} & \multirow[t]{2}{*}{ F-values } \\
\hline & Y & $X$ & A & B & & \\
\hline \multirow{3}{*}{$\begin{array}{l}\text { Japanese } \\
\text { cedar }\end{array}$} & MOE & $\mathrm{DMOEv} / \rho$ & 398.8 & 1.423 & 0.49 & $192^{* *}$ \\
\hline & MOE & DMOEt $/ \rho$ & 466.2 & 0.634 & 0.64 & $355^{* *}$ \\
\hline & MOE & $\mathrm{MOE} / \rho$ & 502.5 & -0.0035 & 0.72 & $494^{* *}$ \\
\hline \multirow{3}{*}{ Taiwania } & MOE & $\mathrm{DMOEv} / \rho$ & 353.8 & 0.162 & 0.56 & $389^{* *}$ \\
\hline & MOE & $\mathrm{DMOEt} / \rho$ & 465.5 & 1.604 & 0.80 & $1197^{* *}$ \\
\hline & MOE & $\mathrm{MOE} / \rho$ & 451 & 0.715 & 0.86 & $1902^{* *}$ \\
\hline \multirow{3}{*}{$\begin{array}{l}\text { Douglas } \\
\text { fir }\end{array}$} & MOE & DMOEv/ $\rho$ & 580.4 & -3.274 & 0.62 & $260^{* *}$ \\
\hline & MOE & DMOEt $/ \rho$ & 587.2 & -1.754 & 0.54 & $192^{* *}$ \\
\hline & MOE & $\mathrm{MOE} / \rho$ & 590 & -1.588 & 0.86 & $962^{* *}$ \\
\hline \multirow{3}{*}{$\begin{array}{l}\text { Southern } \\
\text { pine }\end{array}$} & MOE & DMOEv/ $\rho$ & 642.8 & -1.853 & 0.59 & $177^{* *}$ \\
\hline & MOE & DMOEt $/ \rho$ & 662.9 & -1.245 & 0.60 & $184^{* *}$ \\
\hline & MOE & $\mathrm{MOE} / \rho$ & 654.1 & -0.746 & 0.76 & $391^{*}$ \\
\hline
\end{tabular}


Table 6 - Correlations among DMOEv, DMOEt, and MOE analyzed by linear regression $(Y=A X+B)$ formulae for dimension lumber

\begin{tabular}{|c|c|c|c|c|c|c|}
\hline \multirow[t]{2}{*}{ Species } & \multicolumn{4}{|c|}{ Linear regression model $Y=A X+B$} & \multirow[t]{2}{*}{$R^{2}$} & \multirow[t]{2}{*}{ F-values } \\
\hline & Y & $X$ & A & B & & \\
\hline \multirow{3}{*}{$\begin{array}{l}\text { Japanese } \\
\text { cedar }\end{array}$} & DMOEt & DMOEv & 0.88 & 0.611 & 0.84 & $1025^{* *}$ \\
\hline & MOE & DMOEv & 0.77 & 1.658 & 0.71 & $488^{* *}$ \\
\hline & MOE & DMOEt & 0.88 & 1.058 & 0.86 & $1235^{* *}$ \\
\hline \multirow{3}{*}{ Taiwania } & DMOEt & DMOEv & 0.78 & 1.408 & 0.74 & $835^{* *}$ \\
\hline & MOE & DMOEv & 0.79 & 0.742 & 0.70 & $697^{* *}$ \\
\hline & MOE & DMOEt & 0.99 & -0.480 & 0.90 & $1655^{* *}$ \\
\hline \multirow{3}{*}{$\begin{array}{l}\text { Douglas } \\
\text { fir }\end{array}$} & DMOEt & DMOEv & 0.81 & 1.008 & 0.86 & $959^{* *}$ \\
\hline & MOE & DMOEv & 0.97 & -1.298 & 0.80 & $639^{* *}$ \\
\hline & MOE & DMOEt & 1.11 & -1.462 & 0.83 & $657^{* *}$ \\
\hline \multirow{3}{*}{$\begin{array}{l}\text { Southern } \\
\text { pine }\end{array}$} & DMOEt & DMOEv & 0.89 & 0.657 & 0.92 & $1302^{* *}$ \\
\hline & MOE & DMOEv & 0.94 & -0.429 & 0.82 & $566^{* *}$ \\
\hline & MOE & DMOEt & 1.04 & -0.870 & 0.87 & $526^{* *}$ \\
\hline
\end{tabular}

as a basis for predicting the properties of the lumber. The determined coefficients $\left(R^{2}\right)$ were found to be 0.71 (DMOEv and MOE) and 0.86 (DMOEt and MOE) for Japanese cedar, 0.70 (DMOEv and MOE) and 0.90 (DMOEt and MOE) for Taiwania, 0.80 (DMOEv and MOE) and 0.83 (DMOEt and MOE) for Douglas fir, and 0.82 (DMOEv and MOE) and 0.87 (DMOEt and MOE) for Southern pine. The dynamic MOE versus static MOE values for the combined lumber of the four wood species are also shown in Table 6. The linear regression analysis indicated a strong correlation between the dynamic MOE and static MOE. The $R^{2}$ values were 0.85 and 0.92 for DMOEv to MOE and DMOEt to MOE, respectively. Results indicated that species-independent non-destructive testing methods such as these might offer a feasible alternative to visual grading.

Based on the above results, we determined that the DMOEv and DMOEt were both dynamic and so were highly correlated. There was also a high correlation between the three measurements, DMOEt, DMOEv, and MOE, especially between the DMOEt and MOE, whose $R^{2}$ value was 0.92 for the combined lumber of the four wood species, and that it is a better way to determine the MOE. The strong correlation found was similar to those reported by Haines et al. (1996). They determined Young's modulus values for spruce, fir and isotropic materials by dynamic and static flexure methods and pointed out that the resonance flexure method is a useful tool to determine Young's modulus of wood. Green and McDonald (1993a,b) tested red oak and red maple and found the $R^{2}$ values of 0.92 and 0.85 , respectively. Erikson et al. (2000) determined the DMOEt and MOE values of grand fir and lodgepole pine and found the $R^{2}$ values to be 0.87 and 0.89 , respectively. Burdzik and Nkwera (2002) selected Eucalyptus grandis to determine the DMOEt and MOE; the $R^{2}$ value was 0.813 .

As can be seen from the above information, it may be feasible to evaluate the properties of lumber via the DMOEt, DMOEv and MOE. The dynamic modulus of elasticity as determined by the transverse vibration method was found to be the best single predictor of the MOE. Therefore, this type of non-destructive evaluation could also be used to establish an economic rating and sorting for lumber.

\section{Conclusions}

Based on the experimental work conducted in this study, the following conclusions can be drawn.

1. The higher the visual grading was, the higher the values of DMOE and MOE of the lumber were.

2. Most of the criteria used in the visual grading of the lumber were not closely correlated with specific properties. Visual grading was not as precise as machine grading.

3. The DMOE was greater than the static MOE for the lumber of all four species and the DMOEt was very close to the MOE.

4. There were high correlations among the DMOEt, DMOEv and MOE, especially between the DMOEt and MOE, and this was a better way to determine the static MOE for this lumber. The bending properties of lumber can be successfully evaluated by ultrasonic wave and transverse vibration techniques. Flexural stiffness as determined by transverse vibrations was found to be the best single predictor of the MOE. The accuracy of prediction of the MOE using the DMOEt was shown to be independent of lumber species.

\section{Acknowledgment}

The authors wish to thank the National Science Council of Taiwan for the financial support (NSC93WIB0205012).

\section{REFERENCES}

American Society Testing and Materials, Methods D-198, 1996. Static test of lumber in structural sizes. 
Biblis, E., Meldahl, R., Pitt, D., Carino, H.F., 2004. Predicting flexural properties of dimension lumber from 40-year-old loblolly pine plantation stands. Forest Prod. J. 54, 109-113.

Burdzik, W.M.G., Nkwera, P.D., 2002. Transverse vibration tests for prediction of stiffness and strength properties of full size Eucalyptus grandis. Forest Prod. J. 52, 63-67.

Chinese National Standard 14631, 2002. Structural sawn lumber used in platform construction, Bureau of Standards, Metrology and Inspection, Ministry of Economic Affairs.

Chinese National Standard 14633, 2002. Grading rules of softwood lumber used in platform construction by machine stress rating, Bureau of Standards, Metrology and Inspection, Ministry of Economic Affairs.

Divos, F., Tanaka, T., 1997. Lumber strength estimation by multiple regression. Holzforschung 51, 467-471.

Erikson, R.G., Gorman, T.M., Green, D.W., Graham, D., 2000. Mechanical grading of lumber sawn from small-diameter lodgepole pine, ponderosa pine, and grand fir trees from northern Idaho. Forest Prod. J. 50, 59-65.

Galligan, W.L., Snodgrass, D.V., Crow, G.W., 1977. Machine Stress Rating: Practical Concerns for Lumber Producers, FPL-GTR-7. Forest Products Laboratory, Forest Service, US Department of Agriculture.

Green, D.W., McDonald, K.A., 1993a. Investigation of the mechanical properties of red oak 2 by 4's. Wood Fiber Sci. 25, 35-45.

Green, D.W., McDonald, K.A., 1993b. Mechanical properties of red maple structure lumber. Wood Fiber Sci. 25, 365-374.

Green, D.W., Lowell, E.C., Hernandez, R., 2005. Structural lumber from dense stands of small-diameter Douglas-fir trees. Forest Prod. J. 55, 42-50.

Haines, D.W., Leban, J.M., 1997. Evaluation of the MOE of Norway spruce by the resonance flexure method. Forest Prod. J. 47, 91-93.

Haines, D.W., Leban, J.M., Herbe, C., 1996. Determination of Young's modulus for spruce, fir and isotropic materials by the resonance flexure method with comparisons to static flexure and other dynamic methods. Wood Sci. Technol. 30, 253263.

Iijima, Y., 1993. Wood-base material wood science and utilization technique large scale wooden structure. Jpn. Wood Res. Soc. (Published), 23-62.

Jang, S.S., 2000. Evaluation of lumber properties by applying stress waves to Larch logs grown in Korea. Forest Prod. J. 50, 44-48.

Lin, C.R., Shih, N.Y., Wang, S.Y., 1992. Studies on the lumber grades and bending properties of Japanese cedar and China-fir plantation tree. Quart. J. Exp. Forest Nat. Taiwan Univ. 6, 71-101.
Ross, R.J., Pellerin, R.F., 1991. Stress wave evaluation of green material: preliminary results using dimension lumber. Forest Prod. J. 41, 57-59.

Ross, R.J., Geske, E.A., Larson, G.L., Murphy, J.F., 1991a. Transverse vibration nondestructive testing using a personal computer, Research Paper, FPL-RP-502, Forest Products Laboratory, Forest Service, US Department of Agriculture.

Ross, R.J., Cooper, J., Wang, Z., 1991b. In-place evaluation of fire retardant treated wood products. In: Proceedings of the 8 th International Nondestructive Testing of Wood Symposium, Pullman, WA, Washington State University, pp. 247-252.

Ross, R.J., Fuller, J.J., Dramm, J.R., 1995. Nondestructive evaluation of wetwood and honeywood. In: In the Proceeding of the Hardwood Symposium, pp. 61-67.

Ross, R.J., Bradshaw, B.K., Pellerin, R.F., 1998. Nondestructive evaluation of wood. Forest Prod. J. 48, 14-19.

Ross, R.J., Zerbe, J.I., Wang, X., Green, D.W., Pellerin, R.F., 2005. Stress wave nondestructive evaluation of Douglas-fir peeler cores. Forest Prod. J. 55, 90-94.

Schad, K.C., Kretschmann, D.E., McDonald, K., Ross, R.J., Green, D.W., 1995. Stress Wave Techniques for Determining Quality of Dimension Lumber from Switch Ties, FPL-RN-0265. Forest Products Laboratory, Forest Service, US Department of Agriculture.

Sinclair, A.N., Farshad, M., 1987. A comparison of three methods for determined elastic constants of wood. J. Test. Eval. JTEVA $15,77-86$.

Sobue, N., 1992. Measuring method of the strength related factors. Wood Ind. 47, 13-19.

Wang, Y.R., Chen, P.J., 1990. Study on the in-grade variance of dimension lumber strength distribution. Forest Prod. Ind. 9, 97-109.

Wang, S.Y., Ko, C.Y., 1998. Dynamic modulus of elasticity and bending properties of large beams of Taiwan-grown Japanese cedar from different plantation spacing sites. Mokuzai Gakkaishii 44, 62-68.

Wang, S.Y., Lin, S.H., 1996. Effect of plantation spacing with quality of visually graded limber and mechanical properties of Taiwan-growth Japanese cedar. Mokuzai Gakkaishi 42, 435-444.

Wang, X., Ross, R.J., Mattson, J.A., Erickson, J.R., Forsman, J.W., Geskse, E.A., Wehr, M.A., 2002. Nondestructive evaluation techniques for assessing modulus of elasticity and stiffness of small-diameter logs. Forest Prod. J. 52, 79-85.

Wang, S.Y., Chen, J.H., Hsu, K.P., 2005. Effects of planting density on visually graded lumber and mechanical properties of Taiwania. Wood Fiber Sci. 37, 574-581. 